\title{
Impact of 5S on productivity, quality, organizational climate and industrial safety in Caucho Metal Ltda.
}

\author{
Impacto de las $5 S$ en la productividad, calidad, clima organizacional y seguridad \\ industrial en la empresa Cauchometal Ltda.
}

\author{
Eileen Julieth Hernández Lamprea ${ }^{1} \quad$ Zulieth Melissa Camargo Carreño ${ }^{1}$ \\ Paloma María Teresa Martínez Sánchez ${ }^{1}$
}

Recibido 21 de agosto de 2013, aceptado 23 de mayo de 2014

Received: August 21, $2013 \quad$ Accepted: May 23, 2014

\begin{abstract}
This paper describes a first approach of $5 \mathrm{~S}$ impact on the study factors of quality, productivity, industrial security and organizational climate in the manufacturing area of Small and Medium Enterprises (SMEs) in Colombia, through a case study carried out in a small company located in Bogotá, in order to evaluate whether the $5 \mathrm{~S}$ methodology could be considered as an effective tool to improve manufacturing companies. A visual diagnosis was chosen to identify the area that presented the greater amount of clutter and dirt. Once the location was identified, surveys, performance measures and a risk landscape were performed, focusing on the study factors, in order to understand the initial situation of the area. Subsequently, the implementation of $5 \mathrm{~S}$ was carried out and then three measurements were taken to monitor the performance of the study factors, so as to know if they followed a trend during the measuring period. The results show the existence of a positive relationship between the study factors and the implementation of the $5 \mathrm{~S}$ methodology, since an increase of productivity and quality was evidenced, based on the performance measures as well as an improvement of the organizational climate and a decrease of the risks identified in the workshop.
\end{abstract}

Keywords: 5S methodology, productivity, organizational climate, industrial safety, quality.

\section{RESUMEN}

Este trabajo describe una primera aproximación del impacto de las 55 sobre los factores de estudio de: calidad, productividad, seguridad industrial y el clima organizacional, en el área de fabricación de pequeñas y medianas empresas (PYME) de Colombia, por medio de un estudio de caso realizado en una pequeña empresa ubicada en Bogotá, con el fin de evaluar si la metodología de las $5 \mathrm{~S}$ puede ser considerada como una herramienta eficaz de mejora para las empresas manufactureras. En primera medida se desarrolló un diagnóstico visual e identificar el área que presentaba mayor cantidad de desorden y suciedad en la organización. Una vez identificado el lugar, se realizaron encuestas, medidas de rendimiento y panoramas de riesgo, centrándose en los factores de estudio, para comprender la situación inicial de la zona. Posteriormente, se llevó a cabo la aplicación de 5S y se tomaron tres mediciones para supervisar el rendimiento de los factores de estudio a fin de saber si presentaron una tendencia durante el período de medición. Los resultados muestran la existencia de una relación positiva entre los factores de estudio y la aplicación de la metodología 5S, ya que se evidenció un aumento de la productividad y de calidad basado en las medidas de rendimiento, así como una mejora del clima organizacional y una disminución de los riesgos identificados en el taller.

Palabras clave: 5S, productividad, clima organizacional, seguridad industrial, calidad.

\footnotetext{
1 Ingeniería Industrial. Universidad El Bosque. Av. Cra 9 No 131 A-02. Bogotá, Colombia.

E-mail: ehernandezl@unbosque.edu.co; zcamargo@unbosque.edu.co; martinezpaloma@unbosque.edu.co
} 


\section{INTRODUCTION}

The 5S methodology is considered to be one of the performing operational practices that shows the best results in studies of world class manufacturing [1] because of its contribution to the improvement of processes focused on productivity and quality [1-5], safety [3-4,6-8] and work environment [6-7, 9], with fast results [1, 10-12] and low implementation costs [8]. Nevertheless, the literature adduces that companies worldwide have an elementary perception understanding of the importance and potential of 5S methodology [1], leaving them unable to understand the benefits of the methodology as a strategy to improve performance in decision making and organizational growth [5].

Despite the fact that the methodology is well known in the manufacturing sector, there is little evidence about its implementation because companies are reluctant to use this sort of methodology in a formal way [1]. In another context, companies include some aspects of $5 \mathrm{~S}$ in their routines without being aware of its existence as a formalized technique [12]. More specifically, Colombian companies have not paid enough attention to continuous improvement processes. For this reason the 5S methodology is an underutilized tool in Colombian small a medium companies [11].

The company chosen for this study is within the metal mechanical sector and is located in Bogotá, Colombia. This company produces metal and rubber pieces for the automotive industry. Currently the company operates in a dirty and disorderly environment. This causes several safety problems for their employees which hinders product tracking inside and outside the production process. Additionally, the company does not have control over the finished product, work in progress, reworks and scrap, which makes it very difficult to know the actual level of productivity and quality.

\section{S OVERVIEW}

The 5S methodology arose following the Second World War as part of the quality movement in Japan [13]. However, the term was formalized by Takashi Osada in 1980 [7-8]. The 5S methodology comes from five Japanese words: Seiri, Seiton, Seiso, Seiketsu and Shitsuke.

\section{Seiri (Sort)}

Refers to selecting and sorting the elements of the workplace into two main categories, essential and nonessential, in an effort to remove unused or rarely used elements that accumulate and create disorder $[9,13]$. Hirano proposed sorting tools and materials into specific categories according to relevance or usage because removing things, which are not needed, makes the workplace larger [7]. This, in turn, generates money and space savings rather than having to invest in an expanding workplace [14].

Seiton (Straighten). Straighten refers to making room for each item previously classified as "essential" so that it can be easily accessible. To bring order to the workplace, the items that are classified as "essential" are labeled, sorted and placed according to their frequency of use so that operators can quickly locate them, use them and return them to their proper place $[9,12]$.

Seiso (Sweep). The third "S" seeks to define the optimal conditions of the working environment (including machines, tools, floors and walls) in order to maintain the workspace under ideal conditions [15]. Regularly cleaning the workspace allows operators to identify and eliminate sources of dirt or clutter [16]. One aspect of "Seiso" is to design and implement effective methods which must be integrated into the operators' daily maintenance tasks [12]. However, it is important to clarify that the third "S" also seeks mechanisms to prevent a dirty and disorderly workstation. Some authors explained that cleaning should not only be done at the end of the day, but also have a regular schedule for removing dirt and dust [7, 14].

Seiketsu (Standardize). Standardization involves easily distinguishing a normal situation from an abnormal one by applying simple rules visible to all operators [17]. For standardization each member of the organization must continuously practice the first three S's [9]. To achieve this it is necessary to design obvious and easy to understand visual controls (signs) that allow operators to differentiate between correct and incorrect behaviors [15]. The purpose of this step is to keep the three previous S's as a standard that allows operators to perform their daily activities in a consistent manner. Accordingly, everything should be clearly identified and labeled [16]. 
Shitsuke (Sustain). Discipline consists of making each of the five S's habitual [12, 31-32] working permanently in accordance with the rules, agreements and commitments that were established to implement the methodology [9-17]. To ensure the success of the methodology a commitment is required from the director to encourage the behaviors that each $\mathrm{S}$ demands [14]. One of the key factors to achieve and maintain a successful implementation of the methodology is the execution of regular audits to reveal the status of each $\mathrm{S}$. The audits should be focused on ensuring that specified routines and schedules are being fulfilled. The audit also provides an excellent opportunity to ask questions and provide feedback to stimulate further improvements [17].

\section{STUDY FACTORS}

This study evaluates the effects of the $5 \mathrm{~S}$ methodology upon productivity, industrial safety, organizational climate and quality before and after its implementation. The study factors are defined below:

1. Productivity pertains to how efficiently the resources of any business unit are being used. Thus, productivity can be defined as the relationship established between the amount of goods or services produced and the amount of resources used to produce them $[18,19]$. Other authors refer to productivity as the efficiency in production or simply the quality increased by reducing rework [20-21].

2. Quality may be defined as the degree to which a group of essential characteristics fulfill the consumer's needs or expectations. Likewise, in quality, the primary goals are customer satisfaction and improving processes and outcomes [22-23]. Quality also means doing things right from beginning to end and satisfying the customer's expectations at the lowest cost [24].

3. Industrial Safety is generally understood as a group of rules and principles that ensure the physical integrity of work, and the proper use and maintenance of machines, equipment and tools of the company [25]. Colombian regulations of industrial safety are defined by a Colombian safety decree as a set of activities aimed at the identification and control of the causes of accidents.

4. Organizational Climate refers to the way people perceive the surrounding environment in which organizations interact. These perceptions can be objective, such as related to organizational structures, policies or rules of the organization, or subjective, such as related to cordiality and support, which affect the results of each individual $[18,26]$.

\section{S IMPLEMENTATION}

\section{Launching the Program}

The launch of the program was carried out by the $5 \mathrm{~S}$ team in the company facilities and all staff took part. Through a presentation the workers learned the aim of each $\mathrm{S}$, the potential benefits to be derived from the implementation and the paradigms they had to abandon for a successful implementation. At the end of the presentation some pictures were shown in order to demonstrate the changes that could be achieved.

\section{Seiri-Classification}

For the first $\mathrm{S}$, a red tag was used to identify and remove nonessential items. Red tags were designed so that they were easily readable, utilized and provided all relevant information for each object. The area was adapted to temporarily store the tagged items. The implementation of the first $\mathrm{S}$ started with each item being designated as either essential or nonessential in order to identify those items that did not belong in the area or whose use was negligible. Subsequently, nonessential items were moved to the temporary storage area. Finally, 16 nonessential elements were tagged. The final disposition is explained as follows: three items were discarded, four items were transferred to other areas of the company, five items were sold as scrap metal and three items were re-organized within the workshop.

\section{Seiton-Sort}

Once implementing the first $\mathrm{S}$, training was provided to employees about the sorting process. In order to perform the classification it was necessary to divide the previously classified items as tools, work in progress, templates, samples and machinery supplements because each element required a different space and storage method. Then three classification criteria were established according to the frequency of use: (1) frequently, (2) occasionally and (3) rarely used items. Visual control was used in this step mainly by identifying items. Frequently used tools were organized by creating shadow 
profiles on tool boards. On the other hand, rarely used tools were placed in the toolbox located in a strategic place in the workshop.

An inventory was taken in order to sort the work in progress and then classify it into categories according to their characteristics. Work in progress was stored in baskets painted with different colors to help operators in the WIP location. Additionally, small boards labeled with important information, such as the type and amount of WIP, were placed in front of the baskets. To organize templates and samples, two shelves were manufactured using scrap. Both were labeled with their respective reference using a metal marker. Finally, machinery supplements were separated and organized on a shelf by reference in such a way that the operator could easily identify each supplement.

\section{Seiso (Sweep)}

To start implementing the third S, cleaning days were planned to clean and inspect the workplace. The operators participated in daily five-minute sessions at day's end to clean their work area and all used items. During the monthly sessions an operator wiped each machine, the shelves and the floor carefully in order to identify anomalies. Additionally, operators used a checklist to audit the monthly cleaning session and propose improvement plans to eliminate the previously found anomalies.

\section{Seiketsu (Standardize)}

Once the previous three S's were implemented, visual control was used in order to accomplish standardization. This step included activities such as painting, labeling, and assigning responsibility. Machines, floors and work areas were painted, defined and labeled. Each worker was assigned to look after specific machines and workshop elements in order to create commitment to workshop cleaning.

\section{Shitsuke (Discipline)}

This last step measures the level of the employees' and managers' engagement in the $5 \mathrm{~S}$ implementation. A meeting with managers and operators was carried out to highlight the results of the implementation using comparative photos (Figure 1). To promote good work habits and maintain what had been achieved so far, visual aids were placed in the workshop to provide guidance to operators about the need to maintain order and cleanliness. Finally, audit dates were set to monitor and asses the progress of the methodology in terms of compliance with the standards established in the previous $\mathrm{S}$.
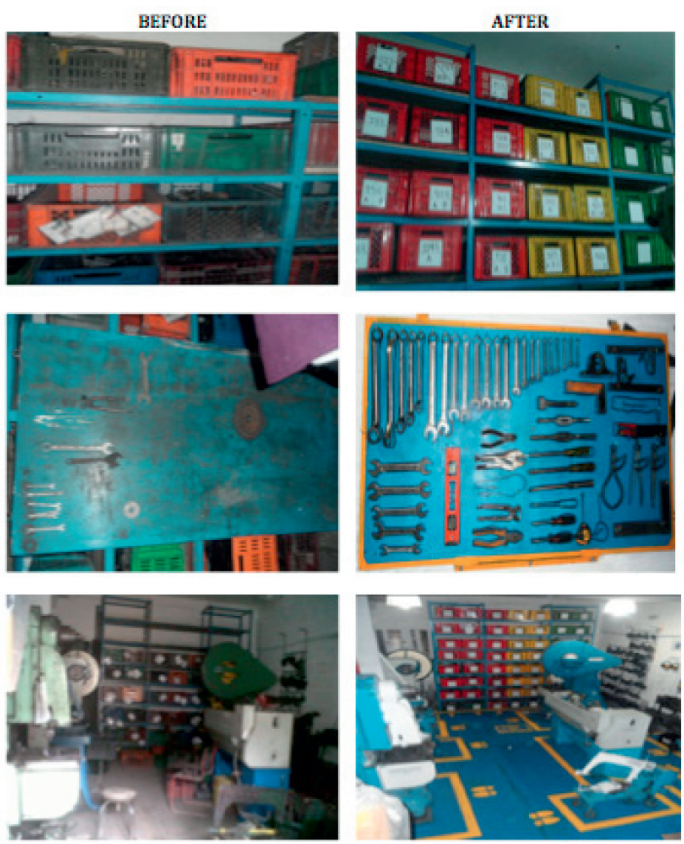

Figure 1. Picture before and after the $5 \mathrm{~S}$ implementation at the workshop.

\section{RESULTS}

\section{Productivity}

Partial productivity indicators [see equations (1), (2), (3) and (4)] were used to measure the productivity in the workshop because these indicators conform to the needs of the project and their variables do not depend on seasonal factors such as sales. As well, partial productivity indicators are the best to show the performance of the manufacturing industry and give feedback in a short period of time [27-28]. It was not possible to use multifactor productivity measure due to the company didn't have information about all factors that include this measure.

$$
\begin{aligned}
& \text { Human Productivity }=\frac{\text { Products } \text { Produced }}{\text { Working Hours }} \\
& \text { Energy Productivity }=\frac{\text { Products Produced }}{\text { Machine Hours }}
\end{aligned}
$$

Capital Productivity $=\frac{\text { Products Produced }}{\text { Capital Input }}$ 
Total Factor Productivity $=\frac{\text { Net Production }}{\text { Input } *(\text { Labor }+ \text { Capital })}$

\section{Human Productivity}

It is evident that the trend in the production of ironworks per hour is upward, given a measured $39.76 \%$ improvement in the efficiency of work between the months of June and September.

\section{Energy Productivity}

In the data obtained during the measurement weeks it is shown that the amount of ironworks processed increases monthly. Overall, from June to September, the efficiency of the machines increased by $30.94 \%$.

\section{Capital Productivity}

Capital productivity trends upward during the months of measurement and it was further observed that the highest peak was reached in September (12.64). The variation in capital productivity from the diagnosis to the last measurement increased the resources invested by $46.20 \%$, indicating that for every dollar invested in stocktaking of raw materials and products in progress, a benefit of $5.84 \%$ was achieved during the measured time.

\section{Total Factor Productivity}

As seen in the obtained data represented in Figure 2, productivity of inputs relating to hand working and capital invested during the months of measurement had an upward trend in the first three months. However, it is observed that in September there was a decline of 0.03 because hand working took a greater percentage of assessed inputs (capital input and hand working). The previous analysis of the indicators that evaluated productivity shows that the impact of the $5 \mathrm{~S}$ implementation was positive in all partial productivity factors, achieving a $32.41 \%$ improvement on average.

\section{Quality}

Non-financial measures were used to measure the quality of the processes carried out in the workshop (see equations (5), (6) and (7)) because they are easy to quantify and understand and focus on the physical process, and therefore help to identify areas where improvement is needed [29].

\section{Percentage of Wasted Material}

The information used in this indicator was based on the number of pieces that could not be reprocessed because the process took too long, and they were not within the control limits allowable for each reference or were simply considered too expensive. This information was compared against the number of pieces in the measurement period.

As shown in the Figure 3, the percentage of rejected or wasted pieces decreased monthly at the rate of 0.0025 . However, in September the wastage rate increased by $0.13 \%$ because the stamping presented a calibration failure.

\section{Percentage of Reprocessed Pieces}

The indicator is constructed based on the number of items processed monthly at the workshop and the number of pieces reprocessed. In the measurements made from June to September it is evidenced that the rate of reprocessed pieces decreased around 0.0058 monthly. It was also found that the rate of reprocessed pieces follows a decreasing trend line, as evidenced in the Figure 3. On the other

$$
\text { Percentage of wasted material }=\frac{\text { Total of damaged pieces per month }}{\text { Total of processed pieces per month }} \times 100
$$

$$
\text { Percentage of reprocessed pieces }=\frac{\text { Total of reprocessed pieces per month }}{\text { Total of processed pieces per month }} \times 100
$$

Percentage of reflected ironworks $=\frac{\text { Total of returned ironworks to the worshop per month }}{\text { Total of processed ironworks per month }} \times 100$ 


\section{Performance Measurement Results relative to Productivity}

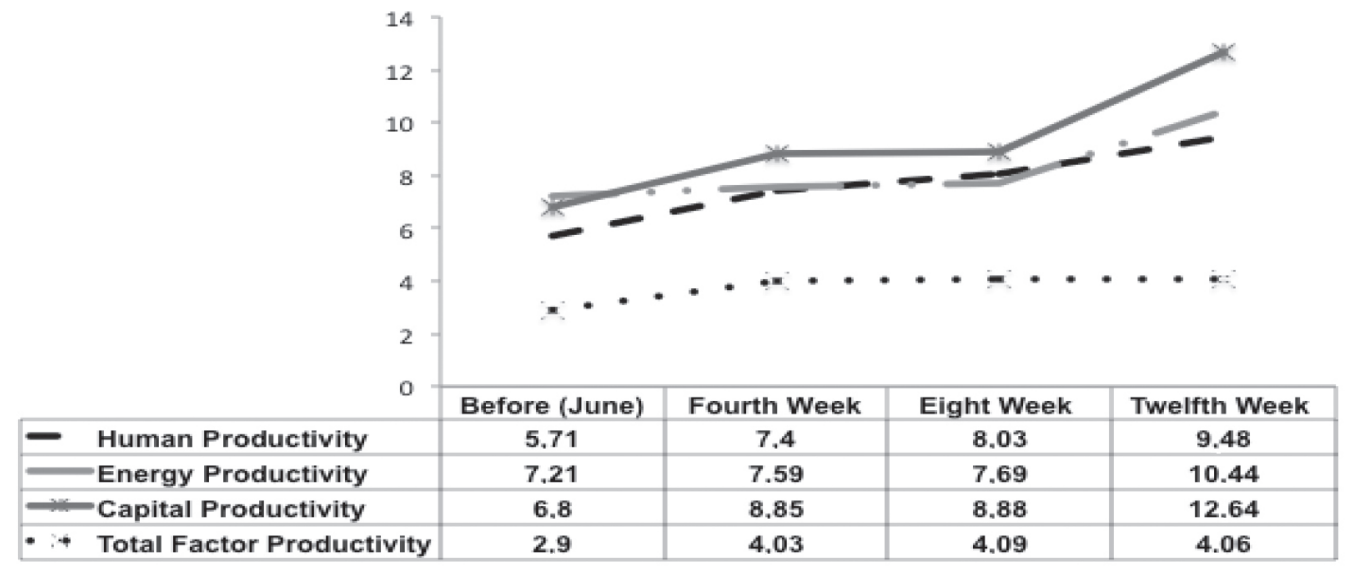

Figure 2. Performance Measurement Results of Productivity.

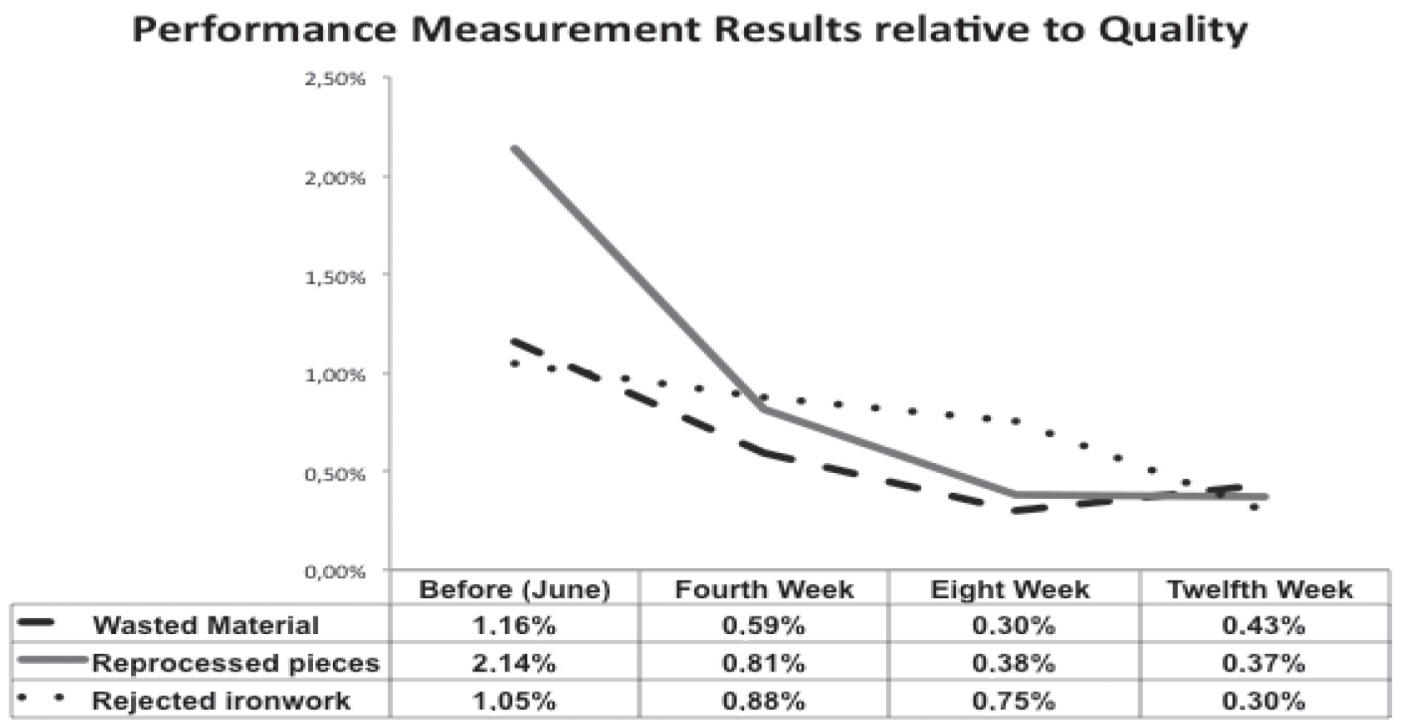

Figure 3. Performance Measurement Results relative to Quality.

hand, the highest peak made from reprocessed pieces occurred in June $(2.14 \%)$ and the lowest one occurred in September (0.37\%). The difference between the measurement months suggests a decrease around $1.77 \%$ from reprocessed pieces during the measurement period, which corresponds to $82.94 \%$ in the rework decrease.

\section{Percentage of Rejected Ironwork}

To develop the indicator the ironworks were taken from the workshop, but they had to be returned because they did not adjust to the vulcanizing mold or the welding quality was not correct. The number of ironworks processed agrees with the amount of blasted ironworks monthly. As shown in the Figure 3, the rejected ironworks rate decreased around 0.0024 monthly, which generated an improvement of $71.42 \%$ (the difference from the first measure, June, until the last one, September) in the returned ironworks that did not satisfy the characteristics and the specification required for the upcoming process. With the data previously obtained for the quality indicators, it was found that the impact of the methodology implementation was positive, achieving 
a $72.35 \%$ decrease on average of processing pieces errors during the measurement period.

\section{Industrial Safety}

Because the company does not have a record of accidents and incidents, any risks the workers were exposed to were visually identified to reveal the current situation of the workshop related to industrial safety and the Colombian Technical Guide (GTC 45) was employed as a measurement tool to help find and minimize these risks. Figure 4 shows a summary of results extracted from the risk matrices developed in June, July, August and September, where you can see the reduction in risk levels compared with June.

\section{Locative Risks}

Locative hazards decreased as a result of $5 \mathrm{~S}$ implementation and new space being created for the piling of raw material used in the manufacturing process. Additionally, visual control was implemented by labeling stairs, work areas and storage areas and removing obstacles in the hallways.

\section{Physical Hazards}

The noise produced by the machinery generated a high risk level that was moderated with the implementation of Seiketsu and the use of visual control tools. Personal protective equipment was strategically located where the operators could see and access it easily. Furthermore, through training, the operators were instructed on the importance and proper use of personal such protective equipment.

\section{Ergonomic}

There was no measured improvement corresponding to the ergonomics risk factor and the poor posture or positioning of the operators. However, a mobile car was built to facilitate the transportation of materials (Figure 4). This new element lowered the risk of injury by allowing the operators to transport work in progress without having to manually carry it themselves.

\section{Mechanical}

With the implementation of the third S (Seiso), sources of dirt and oil leaks were found and eliminated. Also, while cleaning, it was discovered that the two die cutters were missing safety guards and that there were no command labels on the operating buttons. Subsequently, safety guards were applied and all buttons were painted with their appropriate commands.

\section{Electrical}

It was observed that an electrical outlet on a workshop wall was in disrepair and presented a hazard. This was reported to the supervisors along with a recommendation on how to resolve the issue, however the problem persists.

\section{Physicochemical}

Campaigns were developed to foster proper use of personal safety equipment, such as steel-toed boots, goggles, industrial gloves and ear protection, and signage reminding operators of the equipment required to perform their operations was strategically placed throughout the workshop.

\section{Biomechanical}

Operators continue loading and unloading manually, presenting an unacceptable and ongoing risk. As a result of job analysis, responsibilities for each position were distributed evenly among operators and therefore job monotony declined.

\section{Psychosocial}

Problems arose among the workers when someone was unable to locate an item (i.e. tools, samples, patterns, etc.), which was a common occurance given those items were not being properly labeled and stored. With the proper labeling and storage of items, the risk level of conflict among workers decreased.

\section{Organizational Climate}

The TECLA test was used to measure organizational climate because it was developed within the Colombian culture and is one of the models applied by students and consultants in Colombian scope [30]. The questionnaire was completed by the operators, the supervisor and the director of the company to compare the viewpoints of each hierarchical level.

\section{Environmental Conditions}

After 5S implementation both the employees' and managers' perceptions changed so that they now see the workshop as a healthy, safe and comfortable place whereas before they did not.

\section{Communication}

The dimension of communication improved between hierarchical levels within the company, 


\section{Performance Measurement Results relative to Industrial Safety}

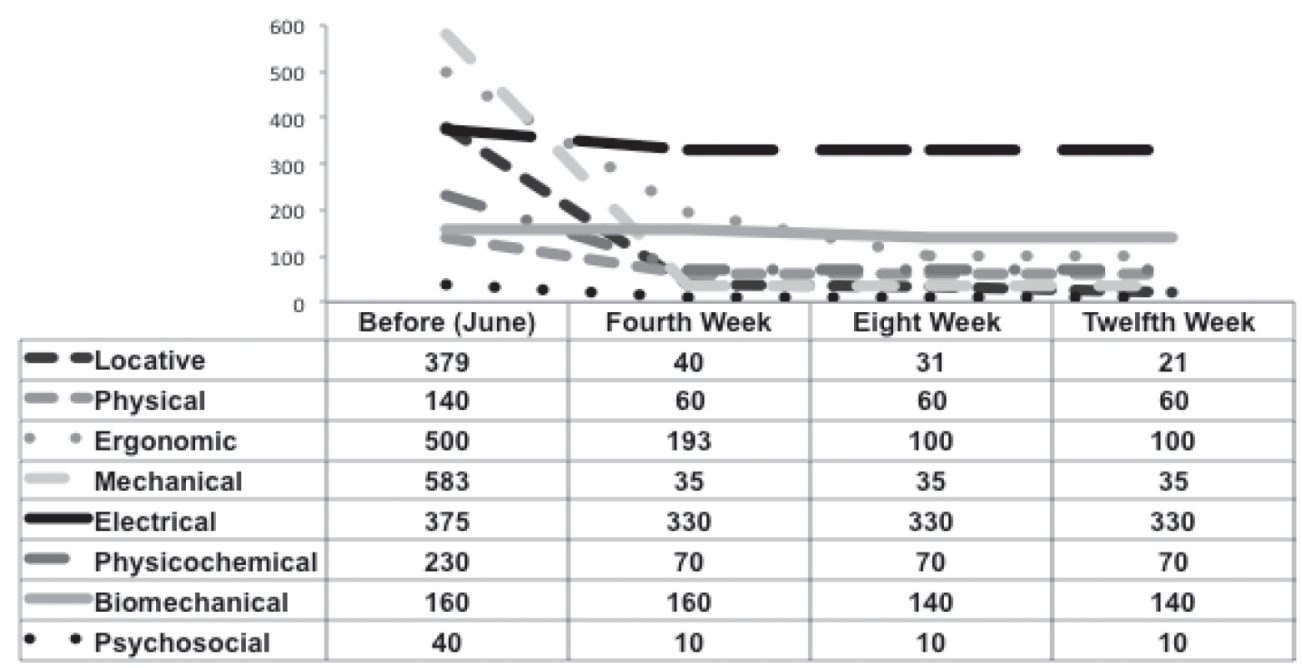

Figure 4. Performance Measurement Results relative to Industrial Safety.

\section{Performance Measurement Results relative to Organizational Climate Survey}

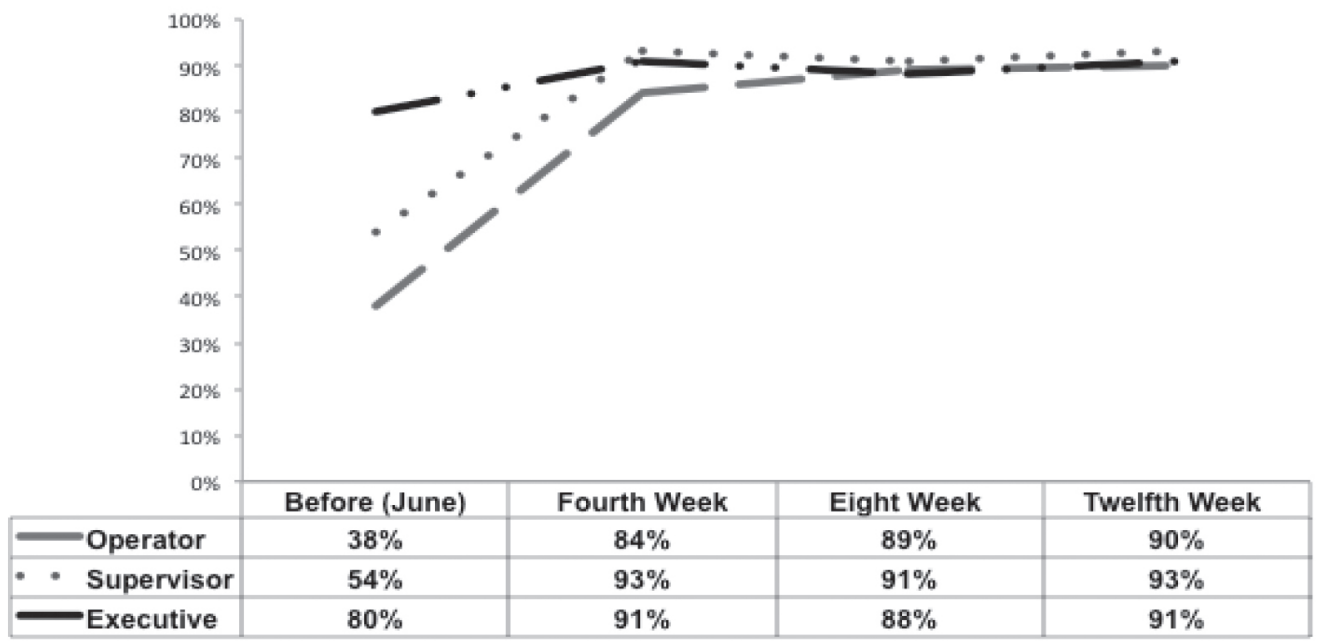

Figure 5. Performance Measurement Results relative to Organizational Climate Survey.

making the the transmission of ideas more precise and explicit.

\section{Structure}

The dimension of structure achieved a $100 \%$ improvement at all levels in September. However, this is not directly related to the $5 \mathrm{~S}$ implementation, but rather is due to the job analysis performed in order to clarify the roles and duties of the workshop operators.

\section{Motivation}

The satisfaction of the operators, supervisor and director all increased after $5 \mathrm{~S}$ implementation because they now identified with the organization's aims. 
Nevertheless, motivation amongst operators and the manager decreased from July to September due to low production levels in July and August during which they were under pressure to increase output.

\section{Cooperation}

To ensure the success of $5 \mathrm{~S}$ implementation, from the beginning it was necessary to establish teamwork, commitment and cooperation at all levels, after which the employees' perceptions regarding this dimension improved.

\section{Sense of Belonging}

As the employees became involved everyone's sense of belonging increased, achieving $100 \%$ for both the director and supervisor.

\section{Labor Relationships}

For successful implementation it was essential that the supervisor and all managers and operators actively participated. Due to such active participation, interpersonal relationships improved on the basis of teamwork.

\section{Leadership}

Additionally, with active participation at all levels, employees engaged each other with greater confidence, which helped the supervisor and managers gain credibility and further develop their leadership abilities. The manager's decrease in his perception of leadership in August was directly related to the noted decrease in the cooperation dimension corresponding to when the manager was not frequently involved in the company's activities. As shown in Figure 5, the organizational climate improved after $5 \mathrm{~S}$ implementation. Nevertheless, during August the compliance rate decreased due to a lack of leadership by the employees and the director after the research group finally departed. It was also evidenced that factors such as management absenteeism, low production and changes in daily functions negatively affected some assessed areas.

\section{CONCLUSIONS}

The study factors' measurements corresponding to the third quarter (July, August and September) were made once the $5 \mathrm{~S}$ methodology was implemented in the workshop. The impact of this methodology on each of the study factors is the following:
- The partial productivity factors of human productivity, energy (facilities), capital and total factor productivity had a positive effect. Their performance improved by $39,76 \% ; 30$, $93 \% ; 30,39 \%$ and $28,57 \%$ respectively.

- Rework and waste issues were notably diminished during the months controlled by the performance indices used. The rates of reworked pieces, wasted pieces and ironwork rejected were reduced by $62.93 \%, 82.94 \%$ and $71.42 \%$ respectively.

- The organizational climate within the workshop achieved improvements in: environment conditions (48.6\%), communication (26.6\%), structure $(53.9 \%)$, motivation $(29.5 \%)$, cooperation $(30.9 \%)$, sense of belonging (36.1\%), labor relations (19.8\%) and leadership $(24.35 \%)$. It should be pointed out that the structure dimension was favored not only by the 5S Methodology, but also by the job analysis and process and procedures manual.

- Regarding industrial safety of the workshop, $85.7 \%$ of the risks sources which had a risk level not accepted now have an accepted one. The workshop's operators now understand the importance of the personal protection equipment and how to use it appropriately.

- In the short term, it was demonstrated that the value all the factors evaluated increased their value, confirming the literature review, which mentions the positive effects the 5S methodology has on quality, productivity, industrial safety and organizational climate of any company.

\section{REFERENCES}

[1] A. Moriones, A. Bello and J. Merino. "Use $5 \mathrm{~S}$ in the manufacturing plants: contextual factor and impact on operating performance". International Journal of Quality and Reliability Management. Vol. 27, Isuue 2, pp. 217-230, 2010. ISSN: 0265-671X.

[2] Business Excellence. "The way business should be done". 2001. Date of visit: June, 2012. URL: http://www.bexcellence.org/5Svisual-management.html 
[3] R. Gapp, R.Fisher and K. Kobayashi. "Implementing $5 \mathrm{~S}$ within a Japanese context an integrated managemet system". Emerald Group Publishing Limited. Vol. 46, Issue 4, pp. 565-579. 2006. ISSN: 0025-1747.

[4] J. Tice, L. Ahouse and T. Larson. "Lean production and EMSs: aligning environmental management with business priorities". Environmental Quality Management. Vol. 15 No 2, pp. 1-12, 2005. ISSN: 1474-6085.

[5] T. Osada. "The 5S: Five Keys to a Total Quality Environment". Asian Productivity Organization, pp. 13-48. Tokyo. 1991.

[6] R. Jumar, C. Sudhahar, J. Dickson, V. Senthil and S. Devadasan. "Performance analysis of 5-S teams using quality circle Financial". Accountant System. The TQM Managine. Vol. 19, Issue 5, pp. 483-493. 2007.

[7] C. HungLing. "5S implementation in Wang Cheng Industry Manufacturing Factory in Taiwan". Master Thesis. Wisconsin University, pp. 8-35. 2011. Date of visit: June, 2012. URL: http://www2.uwstout. edu/content/lib/thesis/2011/2011chih.pdf

[8] R. Gapp, R. Fisher and K. Kobayashi. "Implementing 5S within a Japanese context: an integrated management system". Management Decision, pp. 565-579. 2008. ISSN: 0025-1747.

[9] H. Cura. "Las cinco S: Una filosofia de trabajo, una filosofia de vida", pp. 1-14. Junio 2012. URL: http://www.ucema. edu. ar/productividad/download/2003/Cura.pdf

[10] A. Moriones, A. Bello and J. Merino. "Use $5 \mathrm{~S}$ in the manufacturing plants: contextual factor and impact on operating performance". International Journal of Quality and Reliability Management. Vol. 27, Issue 2, pp. 217-230. 2010. ISSN: 0265-671X.

[11] J.Arrieta. "Las 5S, pilares de la fábrica visual". Revista Universidad EAFIT, pp. 35-48, 1999. ISSN: 0120-341X.

[12] S. Ho. "5 s practice: the first step toward total quality management". Total Quality Management \& Business Excellence. Vol. 10, Issue 3, pp. 345-356, 1999. ISSN: 0954-478X.

[13] J. Michalska and D. Szewieczek. "The 5S methodology as a tool for improving the organization". Journal of Achievements in Materials and Manufacturing Engineering.
Vol. 24, Issue 2, pp. 211-214. 2007. ISSN: 1734-8412.

[14] J. Becker. "Implementing 5S: To promote safety \& housekeeping". Journal professional safety. Vol. 46, Issue 8, pp. 29-31. 2001. ISSN: 1598-2688.

[15] A. Riera y F. Roman. "Asesoría Administrativa Basada en las 5 S Japonesas", pp. 8-56. Fecha de Consulta: Junio 2012. URL: http://dsp ace.ups.edu.ec/bitstream/123456789/688/13/ UPS-CT001712.pdf

[16] E. Giralt. "El concepto de OEE y sus componentes (III)". LogicelPG. Vol. 57, pp. 25-27. 2006. Fecha de consulta: Junio 2012. URL: http://www.galgano.es/wp-content/ uploads/2012/07/xxx060303_El-concepto-deOEE-y-sus-componentes-III_investigacion_ articulos_industria_pdf.pdf

[17] Production Automation Corporation. Date of visit: June, 2012. URL: http://www.gotopac. com/

[18] R. Chase, R. Jacobs y N. Aquilano. "Administración de operaciones: Producción y cadena de suministro". Ttwelfth edition. Mexico D.F. McGraw-Hill/Interamericana Editores S.A, 2009. ISBN: 9789701070277

[19] Business Solutions. pp. 1-5. Date of visit: June, 2012. URL: http://www.bscgla.com/04.\%20 Educacion/00010.\%20Productividad/ Productividad.pdf

[20] C. Syverson. "What determinates productivity?" Journal of Economic Literature. Vol. 49, Issue 2, pp. 326-365. 2011. Date of visit: June, 2012. URL: http:// faculty.chicagobooth.edu/chad.syverson/ research/productivitysurvey.pdf Doi: 10.1257/ jel.49.2.326

[21] E. Deming. Calidad, productividad y competitividad: la salida de la crisis. Madrid: Díaz de Santos S.A. 1989. ISBN: 8487189229.

[22] AENOR, pp. 1-35. Fecha de consulta: Agosto 2012. URL: http://upcommons.upc.edu/pfe/ bitstream/2099.1/3042/4/36146-4.pdf

[23] UMH. Universidad Autónoma del Estado de México, pp. 1-3. Fecha de consulta: Agosto 2012. URL: http://www.uaemex.mx/ planeacion/docs/sgc/Algo\%20acerca $\% 20$ del $\% 20$ concepto $\% 20$ de $\% 20$ calidad.pdf

[24] J. Nebrera. "Introducción a la Calidad". Curso de Calidad por Internet-CCI, pp. 1- 33. 
Fecha de consulta: Junio 2012. URL: http:// www.sld.cu/galerias/pdf/sitios/infodir/ introduccion_a_la_calidad.pdf

[25] R. Méndez. "La estructura de la seguridad industrial". 2009. Fecha de consulta: Junio 2012. URL: http://seguridadindustrialapuntes. blogspot.com/2009/01/qu-es-la-seguridadindustrial-definicin_13.html

[26] L. Castillo, C.Lengua y P.Pérez "Caracterización psicométrica de un instrumento de clima organizacional en el sector educativo universitario Colombiano". International Journal of Psychological Research, pp. 40-47. 2011.

[27] I. Parry and I. Agecon Search, pp. 1-33. Date of visit: August, 2012. URL: http:// ageconsearch.umn.edu/bitstream/10585/1/ dp970039.pdf

[28] C. Leachman, C. Pegels and C. Shin. "Manufacturing Performance: Evaluation and determinants". International Journal of operations and production management. Vol. 25, pp. 851-872. 2005.
[29] A. Uyar. "Quality performance measurement practices in manufacturing companies". The TQM Journal. Vol. 21, Issue 1, pp. 72-86. 2009

[30] N. Patarroyo. "Un modelo para la medicion de clima organizacional, inteligencia emocional, capital conocimiento e imagen empresarial como valores ocultos de una empresa", pp. 1-12. 2001. Fecha de consulta: Junio 2012. URL: http://dspace.uniandes.edu.co/ xmlui/bitstream/handle/1992/125/mi_861. pdf?sequence $=1$

[31] N. Shil. "Explicating 5S: Make you productive". Journal of Contemporary Research in Business. 2009. Date of visit: January, 2014. URL: http://search.proquest. $\mathrm{com} /$ docview $/ 520320823$ ? accountid $=41311$

[32] K. Barcia. "Implementación de una Metodología con la Técnica 5S para Mejorar el Área de Matricería de una Empresa Extrusora de Aluminio". Revista Tecnológica ESPOL, pp. 69-75. 2006. 